Historic, Archive Document

Do not assume content reflects current scientific knowledge, policies, or practices. 



\title{
GLAD GREETINGS from NEW ENGLAND
}

New England. Grown Gladse X - the Best in the Wherdew * DEC $131930 \star$

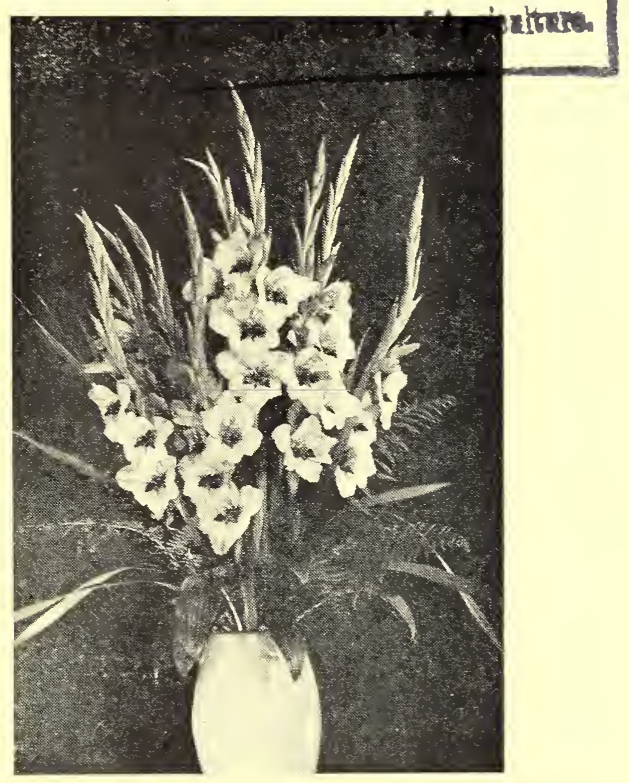

\section{SUNNYMEDE}

Gladiolus: Wondrous color-sprays.

Gorgeous as the clouds in sunset's ray;

Endowed with charming form and dainty grace,

Spires of beauty towering into space:

Floreate clusters: guarding swords of green-

Crown you Nature's wonder and proclaim you Queen. Stanley Thotpe.

\section{WM. EDWIN CLARK}

\author{
SU I I I II E D E
}

SHARON. MASSACHLSETTS, U. S. A.

\section{ำกㄴ.}

- VISITORS ARE IIELCOMETIENTY IILES FROM BOSTON 


\section{SUNYYMEDE GLADIOLLS}

The following collection of "Best" or "Favorite" New England Gladiolus contains most of the beautiful varieties of Eugene $\mathrm{N}$. Fischer; many of Clark Brown's and Gage's; some of A. L. Stephen, Elmer E. Gove, Louis G. Rowe, and a few of my own.

It contains many varieties that have been consistent prize winners in the great Gladiolus Exhibitions held annually at Boston under the auspices of the Massachusetts Horticultural Society and the New England Gladiolus Society.

Although we specialize at "Sunnymede" in New England Originations, we also grow many varieties of other Originators and several of the summer blooming South African Species from which directly and indirectly the present 7000 varieties have been developed.

On another page there is a splendid picture of the exquisite Primulinus Species which grows in South Africa. A few delicate butter-cup colored, butterfly shaped, deeply hooded. widely spaced blooms are borne on a delicate spike. Varieties bred from Primulinus species and having the above characteristics are called primulinus varieties. Those having similar characteristics except that they are larger in size having blooms $3 \mathrm{I} / 2^{\prime \prime}$ or more across are called primulinus grandiflorus.

Although the older type of Gladiolus with large flowers closely spaced on thick stiff stems are of great value for large decorations, yet the newer primulinus and primulinus grandiflorus types which are so much more graceful and decorative are becoming much more popular especially in New England and some parts of old England for table decorations and florists' use.

La Argentina (Clark) (1929) is a primulinus variety on tall slender spike with a good number of florets of the deepest orange red, most unusual. Each $\$ 10.00$

Eleonora Duse (Clark) (1930) is similar to La Argentina, but not as tall and color can be described as deepest orange instead of orange red, slightly lighter than La Argentina. Unusual.

Each $\$ 2.50$

Lady Dainty (Clark) (1929). A primulinus Saundersii hybrid, having the long seg- 
ments or petals and light lower segments of Saundersii. The incured upper segment and yellow base are derived from the primulinus species. The form is beautiful, orchid like, with wavy or undulated segments; color, a light warm pink, with two lower segments cream, blending to pale yellow in throat. According to Ridgeway the upper petals are Harmosa pink blending into geranium pink, while two lower petals are Barium yellow tipped with Harmosa pink. The spikes are very beautiful. At the 1928 Annual Exhibition of the New England Gladiolus Society this, then unnamed seedling, won the N.E.G.S. Silver Metal as the best primulinus seedling in the Show, and the A.G.S. Silver Medal as the best seedling of all types in the Show, and an Award of Merit.

Each \$3.00: per doz. $\$ 30.00$

"Lady Dainty, I would say, is the most beautiful Gladiolus as a cut flower that I have ever seen."

Franklin B. Meade.

Princess Mafalda (Clark) (1929). Blossoms orange pink, shading into light coral red, lower lip yellow shading into coral red, and striped with narrow red lines. A most artistic primulinus variety that makes up into an exquisite bouquet or into a prize winning basket. One of the best, both for exhibitions and as a florist's variety.

Each $\$ 6.00$

Sarah Palfrey (Clark) (1929). Flower of good substance with undulated or wavy segments showing primulinus blood but more open than a primulinus hybrid, measuring $3 \mathrm{I} / \mathrm{s}$ inches. Color is of an even light sulphur yellow, lower segments light yellow with fine red streak. According to Ridgeway, the color is Sulphur yellow. Very dainty and makes a beautiful basket or bouquet. $\quad$ Each $\$ 2.00$

White Prim. (Clark) (19;0). Small white Primulinus. Won silver medal as the best primulinus seedling in the N.E.G.S. Exhibition in August, 1929 Each $\$ 2.00$

Sylvia Crowell (Clark) (1931). Primulinus Variety, with upper three segments of a pale red orange (salmon pink) on a faintly yellow ground, and lower three segments pale yellow with faint blotches of a light to pale red color (pink).

Each $\$ 1.00$ 


\section{"FAVORITE" New England Introductions}

\begin{tabular}{|c|c|c|c|c|}
\hline$P=P$ rim. $\begin{array}{l}P . G=I \\
\text { Introducer }\end{array}$ & $\begin{array}{l}\text { Description } \\
\text { Descrion }\end{array}$ & Each & Doz. & 100 \\
\hline $\begin{array}{l}\text { Adonis, P. G. Brown-Clark } \\
\text { Algonquin }\end{array}$ & $\begin{array}{l}\text { Geranium Pink } \\
\text { Salmon-tall }\end{array}$ & $\begin{array}{r}\$ .10 \\
.40\end{array}$ & $\begin{array}{l}1.00 \\
4.00\end{array}$ & 1.50 \\
\hline Alma Gluck, P. G. Gage & Bright Peach Red & & .60 & 5.00 \\
\hline Annabelle, Prim & Rose, Cream Throat & & 60 & 5.00 \\
\hline melita Galli-Curci, & Dainty, Dp. Orange & 1.00 & 10.00 & \\
\hline Brown-Stephen & Exquisite Ruff Pk & .15 & 1.50 & \\
\hline G. Palmer-Gove & Apricot Shades & .40 & 4.00 & \\
\hline Brown & Resembles Rose Bd & 2.00 & & \\
\hline Benito Mussolini & Soft Pink & 1.00 & 10.00 & \\
\hline $\begin{array}{l}\text { Betty, Prim. } \\
\text { Carnival, P. G. }\end{array}$ & $\begin{array}{l}\text { Salmon } \\
\text { Henna, Speckld Wht }\end{array}$ & 10 & $\begin{array}{r}.60 \\
1.00\end{array}$ & $\begin{array}{l}5.00 \\
7.50\end{array}$ \\
\hline oral Bells, Prim. & Coral-unique & & & \\
\hline $\begin{array}{l}\text { Dawson, Prim. } \\
\text { Dorothy Bishop }\end{array}$ & $\begin{array}{l}\text { Pure Lemon Yellow } \\
\text { Wht Splashed Rose }\end{array}$ & 2.00 & .60 & 5.00 \\
\hline T. Jackson & Dark Velvety Red & & 60 & 5.00 \\
\hline $\begin{array}{l}\text { elle D. Kerr } \\
\text { arrington }\end{array}$ & $\begin{array}{l}\text { Salmon, Self Color } \\
\text { Soft, Self Yellow }\end{array}$ & $\begin{array}{l}.35 \\
.50\end{array}$ & 3.50 & \\
\hline Ethelyn, P. G. & Orange Yel. & .10 & 1.00 & 7.50 \\
\hline Eleonora Duse, Prim. Clark, 1930 & Red & 2.50 & 25.00 & \\
\hline Ella May, Prim & and White & 3.00 & & \\
\hline Elvira, Prim & White, Dainty & .10 & 1.00 & \\
\hline $\begin{array}{l}\text { Fair Harvard, Prim } \\
\text { Fluffy Ruffles, Prim }\end{array}$ & $\begin{array}{l}\text { Deep Harvard Crim. } \\
\text { Fluffy, Pale Yellow }\end{array}$ & $\begin{array}{r}. \\
.10 \\
1.00\end{array}$ & $\begin{array}{r}1.00 \\
10.00\end{array}$ & 7.50 \\
\hline Fischer & Yel. Salmon & .20 & 2.00 & \\
\hline old Elsie & Bright Yellow & .10 & 1.00 & 7.5 \\
\hline Grace Clark Gage-Clark, 1929 & Barium Yel., buff tip & 1.50 & 15.00 & \\
\hline Harmonia, Prim & 1, Self Color & .10 & 1.00 & 7.5 \\
\hline Goehl & Red Blotch & 20 & 2.00 & 15.0 \\
\hline John Alden, Prim & Light Yel. Scar. bltch & h. 15 & 1.50 & \\
\hline Clark, 1929 & Deepest Or. Red & 10.00 & & \\
\hline Lady Dainty, Prim Clark, 1929 & Warm Pink, Cream & 3.00 & 30.00 & \\
\hline Grey & Gy., Lav. Blch & h . 15 & $1.55+30$ & \\
\hline er & Bright Orange Scar. & .50 & 5.00 & \\
\hline & Pk., Red Bch & 25 & 2.50 & \\
\hline apen & ep $\mathrm{Or}$ & 2.00 & 20.00 & \\
\hline Brown & Creamy Salmon & .15 & 1.50 & 11.2 \\
\hline$n, 1930$ & Purple Blotch & 40 & 4.00 & \\
\hline Miss T. Rose & Tea Rose Color & .10 & 1.00 & 7.50 \\
\hline rs. A. Manning, & Bright Pure Yellow & 35 & 3.50 & \\
\hline$F C$ Peterc & Rose Lilac, Blotch & 10 & 1.00 & 7.50 \\
\hline נT & Very Large White & 2.00 & & \\
\hline Wm. E. Clark & Sal. Pk., Crim. Blc & .15 & 1.5 & 11.2 \\
\hline 20 & & & 2.0 & \\
\hline
\end{tabular}

Pierrot, Prim Fischer, 1929 Pink and White $\quad .50$

Portio Fischer Large Creamy White .15

Pride of Sharon Fischer. 1930 White, Crim. Blotch 500

$\begin{array}{llllll}\text { Primadonna, Prim } & \text { Fischer Pure Primrose Yel. } & .10 & 1.00 & 7.50\end{array}$

Prim Queen, Prim Fischer Pure Deep Yeilow $\quad .10 \quad 1.00 \quad 7.50$

Princess Mafalda, P. Clark, 1929 Flesh, Delicate 2.0020 .00

Princess Giovanna, P. Clark, 1930 Delicate Pink 2.0020 .00

Priscilla Alden, P. $\quad$ Fischer Oran£e, Yel. Blch. $\quad .10 \quad 1.00 \quad 7.50$

Rita Beck, P. G. Fischer Immense Fine Pink $.50 \quad 5.00$

Rose Mist, P. G. Fischer Deep Rose, wond'ful .25 2.50

Sarah Palfrey, P. Clark, 1929 Cream, Yel. Center 3.0030 .00

Satellite, Prim Brown Pure Yellow $\quad .60$

Sophie Fischer Fischer Fine Large Pink $.50 \quad 5.00$

Sunnymede Fischer Rare Orange, Blch. $\quad .10 \quad 1.00$

$\begin{array}{llrrr}\text { Tiffany, P. G. } & \text { Brown Pure White } & .10 & 1.00 & 7.50\end{array}$

Twin Fires Fischer Light Pink. two Blch. 20200

Viceroy, P. G. Brown Orange Buff $\quad .60$

Wm. R. Davis Fischer, 1930 White, Blue Spot 5.00 
Many of the following Gladiolus of medium price have scored from 80 to 93.6 per cent, according to the Symposium of the American Gladiolus Society.

\begin{tabular}{|c|c|c|c|c|c|}
\hline$V$ ariety & Introducer & Description & Each & Doz. & \\
\hline Tiplady, Prim & Kunderd & Orange Saffron & & .80 & 6.00 \\
\hline Joseph Hulot & Lemonine & Deep Purple & .10 & 1.00 & \\
\hline n Sylva & Prestgard & Pure White & .10 & 1.00 & 6.00 \\
\hline ine Coleman & Coleman & Coral Pink & 20 & 2.00 & \\
\hline on Glow & Betcher & Glowing Crimson & & .80 & 5.00 \\
\hline y McKibben & Kunderd & Early, Ruffled Pink & & .60 & \\
\hline an Fleet & Kunderd & Oriental Red & & .80 & \\
\hline Shaylor & Kunderd & Rose Pink, Ruffled & & .60 & 0 \\
\hline eth Tabor & Hinkle & Light Pink, Blotch & 10 & 1.00 & \\
\hline Kirtland & Austin & Rosy Pink & 10 & 1.00 & \\
\hline yle & Kunderd & Ruffled, Cream & .10 & 1.00 & \\
\hline Nymph & Coleman & La France Pink & .10 & 1.00 & \\
\hline & Austin & Mauve & & .80 & 0 \\
\hline tor & Hinkle & Beautiful Bright Red & d . .10 & 1.00 & \\
\hline & Kunderd & Pink & .15 & $\begin{array}{r}1.50 \\
.60\end{array}$ & \\
\hline $\begin{array}{l}\text { lrechal Foch } \\
\text { llow }\end{array}$ & $\begin{array}{l}\text { 1. Deursen } \\
\text { Decorah }\end{array}$ & $\begin{array}{l}\text { Cameo Pink } \\
\text { Pink }\end{array}$ & .20 & 2.00 & U \\
\hline eles & Houdeshel & Pink & .10 & 1.00 & \\
\hline aiden's Blush, Prim & Grulleman & Flesh Pink & .10 & 1.00 & 6.00 \\
\hline ickford & Kunderd & Creamy White & & .60 & 5. \\
\hline & Kunderd & Rose Pink, Blotch & & .80 & \\
\hline Frank Pendleton & n Kunderd & Rose Pink, Bloch & & .80 & 6.00 \\
\hline Jeog & Kunderd & Dark Red & .10 & 1.00 & \\
\hline & Groff & White, Large, Late & & .80 & 6.00 \\
\hline & Diener & Ashes of Roses & 10 & 1.00 & \\
\hline & Coleman & Coral Red, Blotch & 10 & 1.00 & 7.50 \\
\hline & Sprague & Pink & .25 & 2.50 & \\
\hline
\end{tabular}
African Gladiolus Species

There are over 100 African Gladiolus species. Psittacinus, meaning parrot's head, bright red and yellow: Drucocephalus. dragon's head. green with purple veins: Primulinus, primrose yellow: and Saundersii, red with white throat, much resembling a beautiful lily, grow well in New England and are a source of delight in the Gladiolus field and get much comment and many medals at exhibitions.

$$
\text { African Species Each Doz. }
$$

Psittacinus, red and yellow, hooded \$ $.50 \quad 5.00$

Dracocephalus, green veined purple $.15 \quad 1.50$

Primulinus, primrose yellow, hooded .20 2.00

Saundersii, red, white throat, lily like 10.00

Sunnymede Mixtures

Sunnymede Mixtutes-All Blooming Size

Mixture No. 1 - 50 bulbs

Mixture No. 2- 300 bulbs

$\$ 1.00$

5.00

Mixture No. 3- 700 bulbs 10.00

Mixture No. 4-1800 bulbs $\quad 25.00$

Mixture No. 5-5000 bulbs $\quad 50.00$

Delphiniums. Many shades of blue, raised from English strain, two year old plants.

$\$ 2.50$ per doz.: $\$ 1.25$ per six.

Old Fashioned Clove Pinks. Such as grew in my grandmother's garden. $\quad \$ 2.00$ per doz. 
Scotch Sea Pink. Very fine for rock gardens and for garden borders. $\$ .35$ ea.; $\$ 3.50$ per doz. Japanese Irises. $\$ 3.50$ per doz.; $\$ 10.00$ per 50 . Phlox-Europe. White with carmine eye.

Wellesley. Deep pink-much like Elizabeth Campbell.

Snow Flake. New white Clark seedling; very fluffy with large bloom.

Lillian. An improvement on Europe; Clark's seedling.

All Phlox is \$.35 each clump; $\$ 3.50$ per doz. clumps (not single spikes).

Sweet William. Mixed colors. $\$ 2.00$ per doz.

Two hundred varieties of Irises, including several varieties of Dwarf Irises, sold from the nurseries only. Visitors are welcome in May and June to visit Sunnymede and choose by name and color the Irises they may wish to buy. Orders taken at that time delivered in July.

$$
\text { Peonies }
$$

Baroness Schroeder. Flesh color

Cherty Hill. Deep garnet

Mikado. Single, Japanese. Crimson $\quad 2.50$

Mrs. Key. Single, Satin crimson 1.00

Admiral Togo. Deep crimson

Collection of Dahlias for $\$ 2.50$ for five different colors

Peg o' My Heart. Rose color.

Pride of California. Deep red.

Estelle Christy. Yellow.

Mrs. Ethel Smith. White shading to lemon, Millionaire. Lovely lavender.

Norway Spruce (18 to 24 inches)

Hemlock Sptuce (18 to 24)

Each $\$ 1.00$

American Arbot Vitae (24 to 36)

Pinus Austrica (6 ft.)

Berberis Thumbergis Doz.

Oralis Spinosa

2.00

White Pine ( 3 to $5 \mathrm{ft}$.)

2.00

1.00 and 2.00

If you are a garden lover you should become a member of America's greatest horticultural society-The Massachusetts Horticultural Society. Annual dues, with Hotticulture, \$2.00.

Annual Membership in the British Gladiolus Society, \$1.40, including valuable Annual.

Annual Membership in the Royal Horticultural Society, one guinea.

The Gladiolus Book by Forman T. McLean, Ph.D., William Edwin Clark, S.B., F.R.H.S., and Eugene N. Fischer, the noted Hybridist, published by Doubleday Page \& Co., has 224 pages. plus complete index, profusely illustrated in color-price $\$ 5.10$ per copy post-paid. 

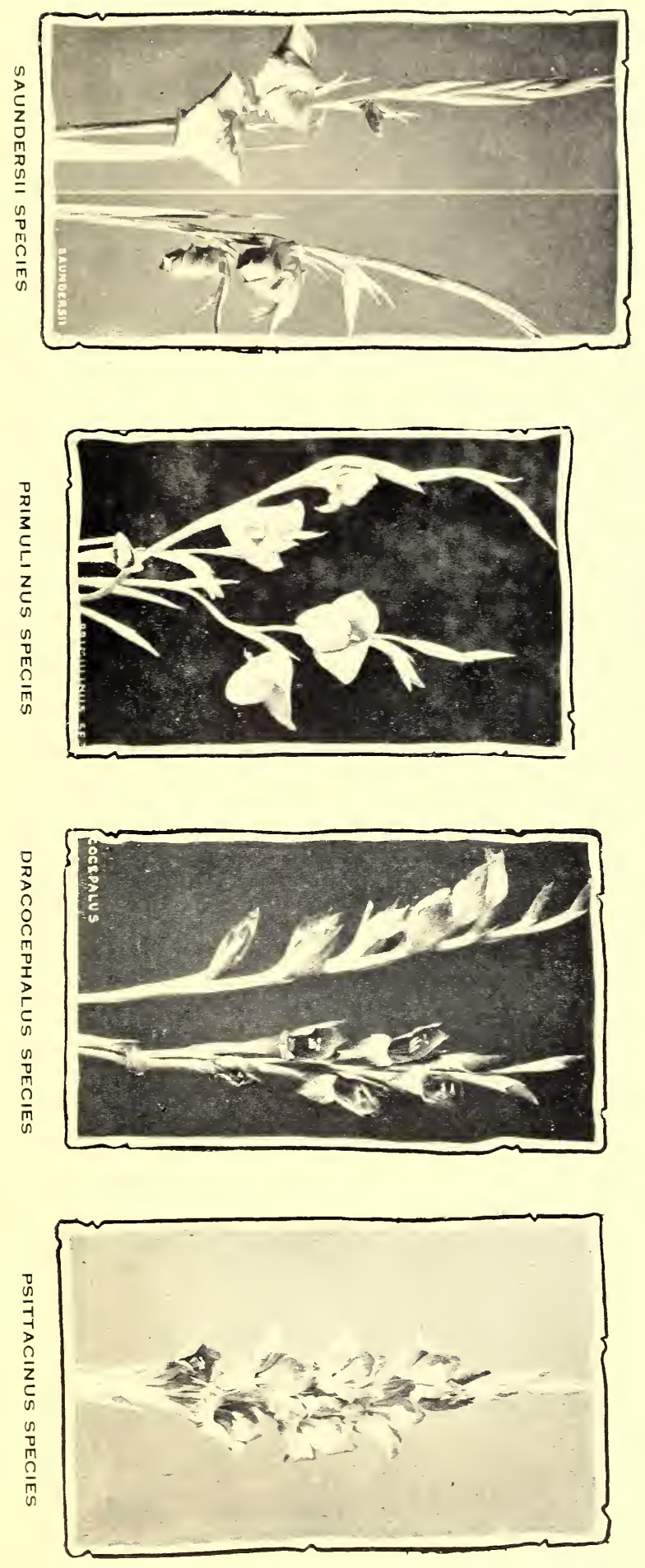
Iris Orientalis

A most beautiful and decorative variety, especially effective in masses and as borders

When Mr. Peter Barr found this iris in Japan and brought it to iris lovers in America, he introduced to this country one of the most beautiful and decorative irises we have in our gardens today. This was not an easy plant to bring to this country, because if one wishes to pack this species for any length of time it is a very difficult thing to do. However, Mr. Barr succeeded in bringing over both Snow Queen and Blue King, and we owe him a vote of thanks for doing so.

To my mind there is not an iris of any other species that makes the wonderful display as does the Orientalis. It is beautiful in masses and whether it borders a drive or is planted on the edge of a pond it gives masses of lovely bloom. lasting for a long time after the standard varieties have long since faded. It likes sunlight but some of mine, planted in the woods on the edge of a small pool, blossom profusely. It will grow in dry or damp places but not in water, as does the Pseudacorus. The tall, grasslike leaves are very ornamental in summer and form masses of green foliage throughout the spring and fall. One clump in a garden is very ornamental. Rows upon rows of these irises. planted two or three feet apart, resemble yards and yards of blue and white ribbon.

At Sunnymede Gardens, when the first dwarf irises come into blossom, we are impatient for the Orientalis and can hardly wait until some fine sunny morning about the middle of June, when these seem literally to burst into bloom. Blue King bears handsome, clear blue-purple flowers on tall stems. Snow Queen is a large, ivory-white flower, having a distinct orange marking on its throat. Both of these are wonderful irises for cutting and many of the florists who are looking for rare and beautiful things, buy these from Sunnymede each year.

The plants are very inexpensive. Blue King is twenty-five cents each, or if bought by the hundred would be ten cents apiece. Snow Queen is thirty cents each. or by the hundred twelve cents each. They are ready for delivery after July 1 st.

SUNNYMEDE GARDENS.

Sharon, Massachusetts. 